\section{SOI: 1.1/TAS DOI: 10.15863/TAS International Scientific Journal Theoretical \& Applied Science}

p-ISSN: 2308-4944 (print) e-ISSN: 2409-0085 (online)

Year: $2018 \quad$ Issue: $01 \quad$ Volume: 57

Published: 15.01.2018 http://T-Science.org
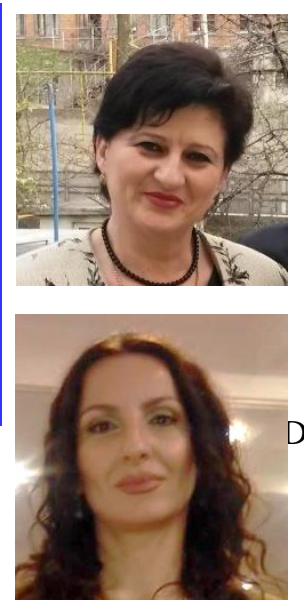

M.G. Grdzelidze

Doctor of Technical Sciences,

Professor of the Department

"Design and Technology",

Dean of Engineering Technological

Faculty of Akaki Tsereteli State

University, Kutaisi, Georgia

L.G. Kiknavelidze

PhD student, Teacher of the Department "Design and Technology",

Akaki Tsereteli State University,

Kutaisi, Georgia

\title{
MODERN CONDITIONS OF THE STUDY OF LEATHER ETHNO- CRAFTS EVOLUTION IN PROBLEMATICS OF RESEARCHING GEORGIAN MATERIAL CULTURE HERITAGE
}

\footnotetext{
Abstract: There are numerous of scientific works about the historical development of Georgian material culture. But the footwear and leather items of Georgian origins exhibited in museums and enclosed in depositories locally and abroad, archive materials about them, iconic and written sources, are not still perfectly studied and systematized, as the footwear and leather items belong to the constructively and technologically complex products.

The article disscuses about the fragments of monuments and material culture models discovered in Georgia existing before $X$ century.

Key words: Evolution of footwear; ethno-footwear; leather products; material culture.

Language: English

Citation: Grdzelidze MG, Kiknavelidze LG (2018) MODERN CONDITIONS OF THE STUDY OF LEATHER ETHNO-CRAFTS EVOLUTION IN PROBLEMATICS OF RESEARCHING GEORGIAN MATERIAL CULTURE HERITAGE. ISJ Theoretical \& Applied Science, 01 (57): 24-28.

Soi: http://s-o-i.org/1.1/TAS-01-57-4 Doi: crossef https://dx.doi.org/10.15863/TAS.2018.01.57.4
}

\section{Introduction}

In the plural problems of study of material culture of Georgia, Georgian garments take a significant place, as it has passed a long way of development. Creation of clothes by human's hand is connected to its utilitarian functions - to protect him from undesirable influence from nature. The required materials of clothing, construction, the rule of its creation, wearing and dressing was stipulated by the climatic-geographical, social-economical, sex-age, economic-domestic conditions. Any change of one of these factors correspondingly caused changes of the furnishings, clothes and changes of leather products along it. These changes were well reflected in ethnographic life.

We can assume that the leather products were widespread in Georgia and in Caucasian population in general. The bases of this assumption is a fact that the sheep-farming was well developed on this territory. On its early stages of development, human being realized the demand of creating the safety means for the feet (primitive footwear). Practically it has a vital importance in the development and perfection of the human thinking, because its evolution is thought as one of the characteristics of human development stages. Also, it gives us opportunity to monitor and track the development of manufacturing means in Georgia, because the changing process of it, as the determinant of development stage if society, was in progress for a long time. The development of it supported the reduction of change duration of leather crafts' construction. The perfection process of working tools, lifestyle (nomadic life or stable style), social hierarchy, geographical location and others had the impact on the alteration of the construction.

\section{Materials and Methods}

From the analyses of sources about historical development of Georgian lifestyle it turns out that clothing, accessories, furnishings have not been studied and analysed perfectly from the point of historical, ethnical, construction-technological and used material aspects. This is confirmed by the numerous scientific works, literary sources, material and web-catalogues performed in this direction (The records of later period of Georgian and other authos: Vakhushti Batonishvili, Ioane Batonishvili, Papuna 
Orrbeliani and others; "The Book of Dowry"; The works of the funder of Georgian lifestyle researches - Ivane Javakhishvili; Recors of I. Tsitsishvili, N. Chopikashvili, G. Chitaia, G. Jalabadze, T. Bezarashvili, and also of the foreign travelers Iosipha Barbaro, Archangelo Lambert, Jan Sharden and others) [1]. The clothing is characterized in many aspects in those Works, in particular: materials, colors, texture, constructions, patterns, technologies, auxiliary and decorative furniture used, embroidery and so on. After the acquaintance of them the person has the perfect image of this significant part of the Georgian culture and the characteristics of Georgian ethnos. But, despite the diversity of this Works, scientific studies haven't touched at the proper level to the footwear and leather product, which were the companion of the whole period of human development. There is only a shallow description of the footwear and other leather crafts in the abovementioned works. In particular: their age, social and geographical origins and functions (in case of leather utensils). But there is no information about the ways of obtaining materials (species of animals), the techniques of processing and conservations, the crafts' types, styles, shapes and sizes, number of details in the crafts and changes of the pattern configuration, dynamics of methods for sewing the craft, qualifications of craftsmen and quality of performing technical works, the levels of consumerutilitarian functions (comfortableness), implementing the new construction and details for this purpose, the methods for linkage of details, means, quality of mastership, the durability in the process of usage, visual relevance of footwear and leather crafts with the clothing and so on. The most interesting part is the surface of the shoes, the bottom, the construction of a heel, the evolution of them and the means and methods of linking them. The history of development of leather crafts can't be considered as studied without the answering those questions.

The insufficient information about the Georgian ethno-items isn't the only reason why those items are remained in very less amounts compared to other material heritages, but the main reason is the shortage of the professionals of this field. The analyses of leather items require not only the knowledge and experience in the direction of ethnologic and archeologic direction, but also the knowledge and skills in the field of footwear and leather product research. The necessity of it is stipulated by the multilateral (material knowledge, construction, technological and etc.) complexity of this items.

In the historical sources survived Georgian and foreign researchers and travelers explain the diversity and variability of Georgian clothing by the historical and natural-relief conditions [2]. The geographical location of the country, connection with neighbor countries, trade relationships and Silk Road, difference in climate of mountains and valley, east and west, regional traditions - established the different style of dressing. All the above mentioned conditions have been influencing the variation of footwear construction. This is confirmed by those few material heritage which is preserved today.

Retained traditions of crating leather handicrafts in mountainous villages have gained significant interest for its uniqueness, like clothing has. Their style, design, shape of the surface and heel, and the methods for linking details are very interesting and only the visual inspection of it can speak for the unique technique of craftsmanship. Because the leather items exhibited in Georgian museums or preserved in stores, the feudal sources about them, the frescoes and bas-reliefs remaining in cultic temples, miniatures in handwritings, iconographic and written sources, notices of foreign travelers aren't perfectly studied yet, they don't give us a clear image of the history of developing the construction of footwear and leather items in Georgia, correspondingly,

Our team got interested in the historicethnographic sources and materials related to the traditional Georgian footwear. The study of the sources revealed that in Georgia production and use of footwear started in the second millennium BC. The study also revealed the evolutionary stages, production means, constructional features, technology, materials, variety of surface treatment methods, decor, shape and color of the footwear, which were influenced by both Western and Eastern cultures as well as Georgia's historical and geopolitical conditions. In this period we have found materials about the development of constructional features of Georgian traditional footwear, according to which we have described the stages of development of Georgian traditional footwear and have restored the construction and illustrated it:

1. The Ancient Age - a ritual shoe with a curling tip (chvinti) dating back to the second millennium BC (figure 1), which is very similar to tsagha (an ankle-length boot) and supposed to be the predecessor of khamli (a woman's shoe). It is carved out on the silver bowl from the Trialeti archaeological material dating to the Middle Bronze Age. The bowl depicts a ritual process featuring twenty masked men wearing fur-trimmed coats and shoes with curling tips. And because it was a ritual shoe, we can assume that there were also a different purpose shoes, ie. household shoes, presumably primitive kalamani (bast sandals) [1].

2. Ancient Age - The engraved bronze belt found in Stepantsminda (Figure 2), dating back to the first millennium $\mathrm{BC}$. The shoe is depicted on the surface of the belt. The footware printed on the surface of other ithyphallic items found in Stepantsminda represents a new type of traditional footwear from The Iron Age - top boots. The 


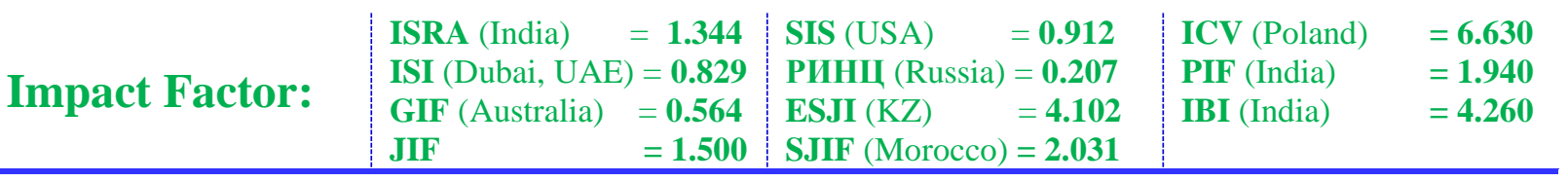

Stepantsminda bronze belt gives us rich information millennium BC [3]. to determine the types of footwear from the first
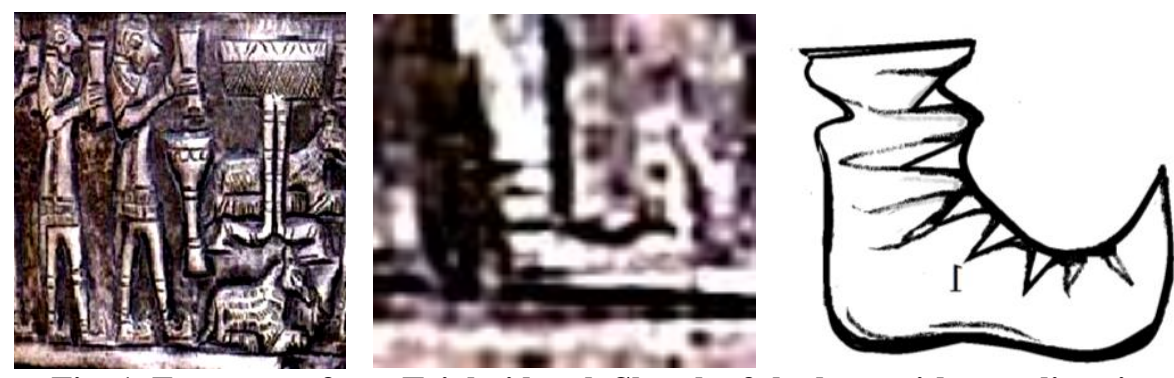

Fig. 1. Fragments from Trialeti bowl. Skatch of the boot with a curling tip.
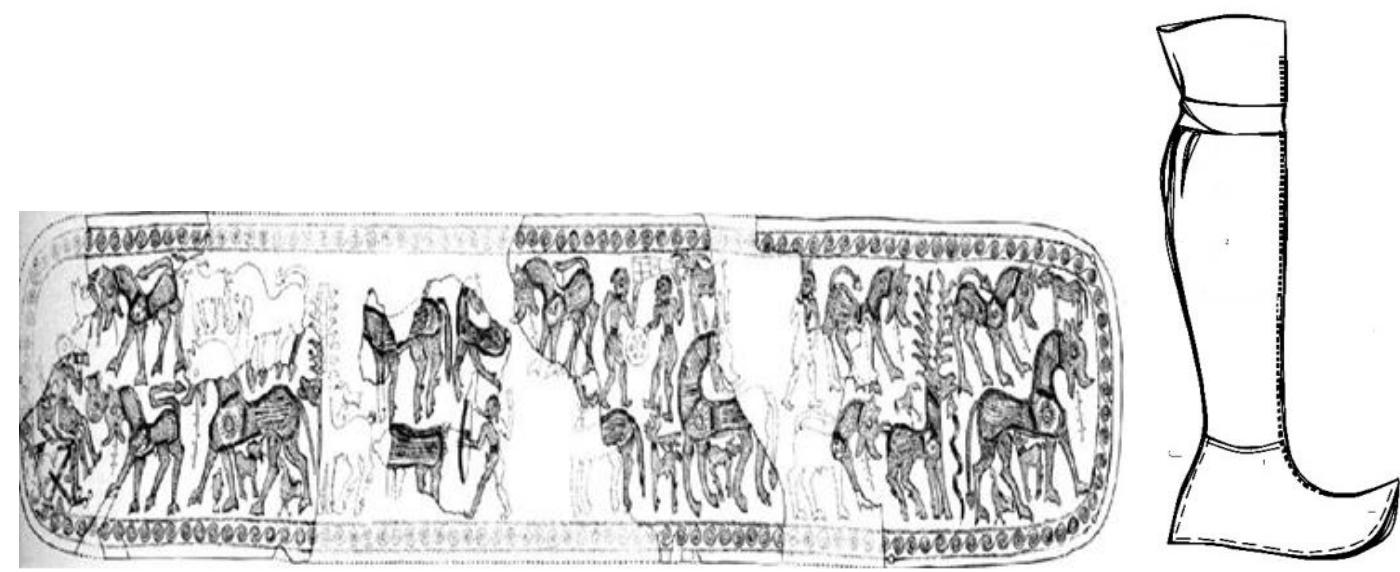

Fig. 2. Bronze belt, sketch of Botford type boot.

3. Late-antique period - in III-IV centuries the first term for the Georgian ethno-footwear is "Khamli" (fig. 3), description of it exists only in written and literature sources. It looked like a boot and was tied by the rope $[4,5]$.

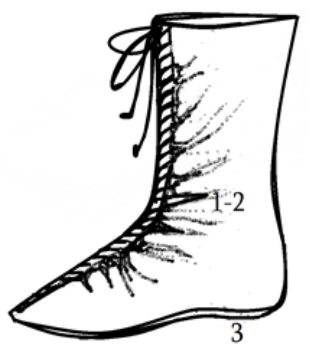

Fig. 3. The sketch of "khamli".

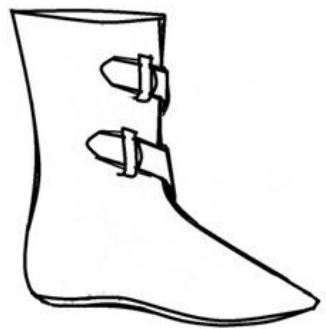

Fig. 4. New kind of "khamli", with bronze buckles.

4. V-VI - A.D. - "khamli" sewed with a new manner with bronze buckles (fig. 4) [6, 7]. 


\begin{tabular}{l|lr|ll|ll} 
& ISRA (India) & $=\mathbf{1 . 3 4 4}$ & SIS (USA) & $=\mathbf{0 . 9 1 2}$ & ICV (Poland) & $=\mathbf{6 . 6 3 0}$ \\
Impact Factor: & ISI (Dubai, UAE) $=\mathbf{0 . 8 2 9}$ & PUHI (Russia) & $=\mathbf{0 . 2 0 7}$ & PIF (India) & $=\mathbf{1 . 9 4 0}$ \\
& GIF (Australia) & $=\mathbf{0 . 5 6 4}$ & ESJI (KZ) & $=4.102$ & IBI (India) & $\mathbf{4 . 2 6 0}$ \\
& JIF & $=\mathbf{1 . 5 0 0}$ & SJIF (Morocco) & $=\mathbf{2 . 0 3 1}$ & & \\
\hline
\end{tabular}

5. In VII-VIII centuries - sandals, flat anklehigh slipper type “mogvi” and high ,mogvi” appear [8].

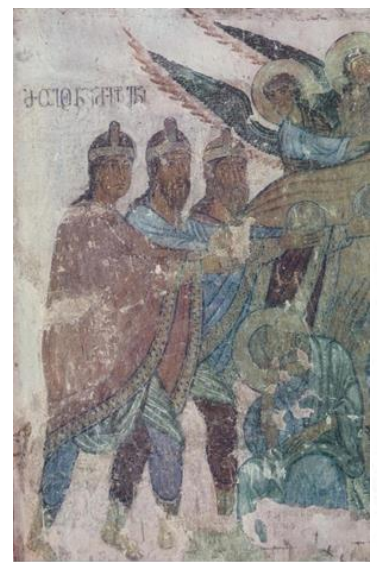

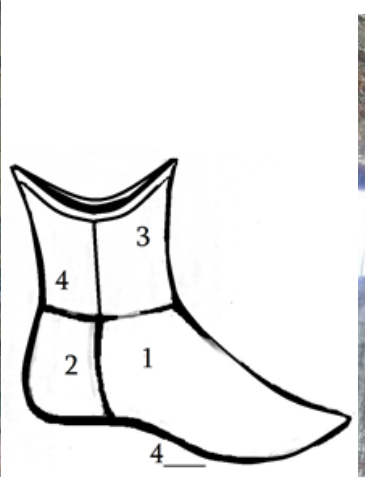

b

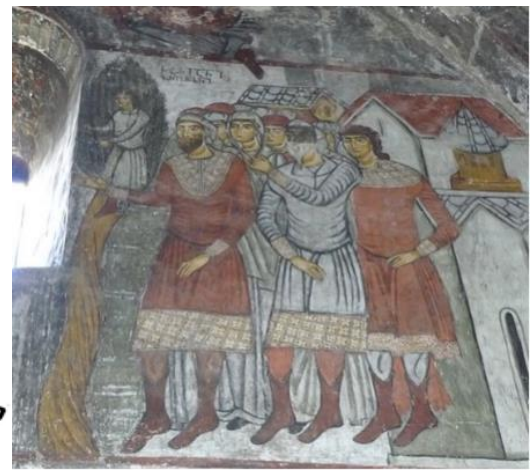

C

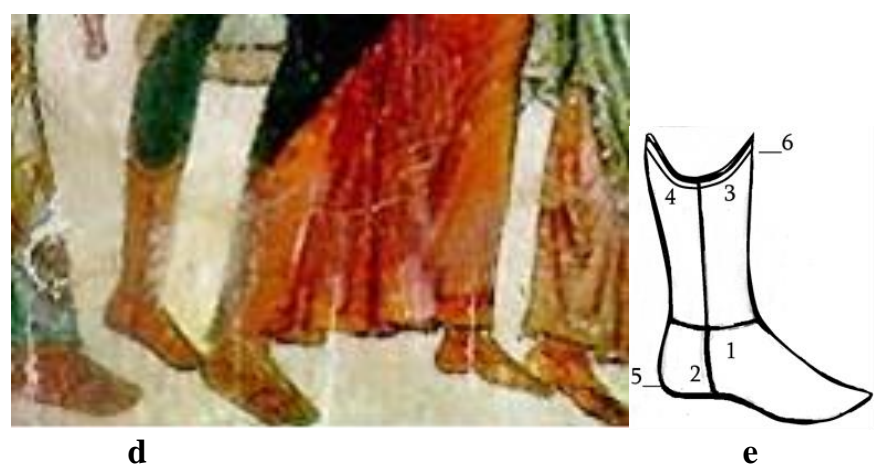

Fig. 5. a) Atenis Sioni VII Century; b) flat ankle-high slipper type "mogvi" in Matskhvari VIII century; c) Palm Sunday - fragment; d) Atenis Sioni VII century, high "mogvi" boot; e) high "mogvi" boot.

6. In IX-X high "mogvi" boot with heel is widespread. Low-heeled shoe - clogs, flat-heeled shoe were used by the high social class, sandals and slippers were intended for lower classes (fig.6) [9, 10].

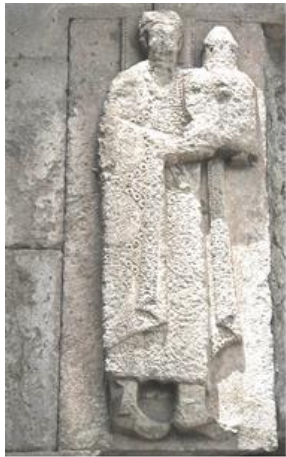

a

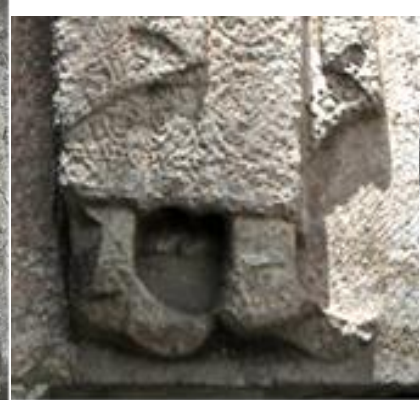

b

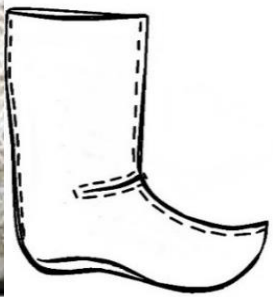

c

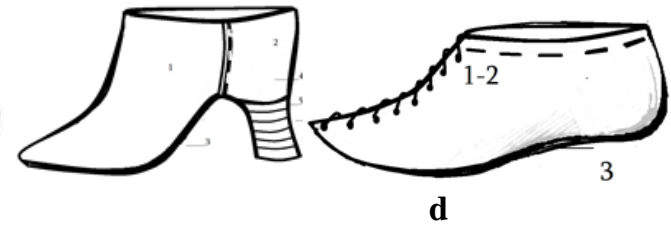

d

Fig. 6. a) Davit III Kuropalates, Oshki X century; b) high boot - chapla; c) "mogvi" boot, skatch; d) bast shoe.

\section{Conclusion}

The fact, that the leather items remained are damaged because of their age and there is a threat of extinction makes our objective harder. Because these items are made with a natural leather, which as an organic material is being decomposed and destructed over time (despite the storing conditions and the quality of processing the material). The time negatively impacts on the leather, so the only way of saving and preserving them for the nation is to create 


\begin{tabular}{|c|c|c|c|c|c|c|}
\hline Impact Factor: & $\begin{array}{l}\text { ISRA (India) } \\
\text { ISI (Dubai, UAE } \\
\text { GIF (Australia) } \\
\text { JIF }\end{array}$ & $\begin{array}{l}=1.344 \\
=0.829 \\
=0.564 \\
=1.500\end{array}$ & $\begin{array}{l}\text { SIS (USA) } \\
\text { PИHЦ (Russia } \\
\text { ESJI (KZ) } \\
\text { SJIF (Morocco }\end{array}$ & $\begin{array}{l}=0.912 \\
=\mathbf{0 . 2 0 7} \\
=\mathbf{4 . 1 0 2} \\
=\mathbf{2 . 0 3 1}\end{array}$ & $\begin{array}{l}\text { ICV (Poland) } \\
\text { PIF (India) } \\
\text { IBI (India) }\end{array}$ & $\begin{array}{l}=6.630 \\
=1.940 \\
=4.260\end{array}$ \\
\hline
\end{tabular}

complete illustrative, cognitive catalogue (the analogue of which hasn't been created yet in Georgia) by systemizing the research findings.

Georgia is an ancient country with unique and rich traditions, which always inspires foreign researchers with its diverse material and spiritual culture, has been acquainted by the world already.
So, it would be the greatest step to research and shed light to the evolution history of very important, and yet unknown, Georgian culture element - leather ethno-items, for the Georgian national material culture studying. This issue is very actual for Georgia in order to study the past of its material culture and for popularization of the country.

\section{References:}

1. (2018) The Trialeti Silver Cup, 1 Millennium, is exhibited at the Exhibition of Simon Janashia Museum of Georgia - "Archaeological Treasures".

2. (2018) http://mastsavlebeli.ge/?p=1385 Available: 10.01.2018).

3. (2014) Metal-sculpture. National Treasure. Forum - Art.

4. Ivane Javakhishvili (1970) History of Georgian Nation. Tbilisi State University, Tbilisi, t. 1. p. 8-37.

5. N. Khoshtaria (1970) "Archaeological Monuments of the Antique epoch in Western
Georgia" Archeology of Georgia. Tbilisi. p. 247.

6. (1973) Essays on Georgian History, vol. II (Georgia IV-XI centuries).. Tbilisi. p. 506.

7. Ivane Javakhishvili (1979) History of Georgian Nation. Tbilisi State University, Tbilisi, t. 2. p. 363.

8. Sulkhan-Saba Orbeliani (1970) Dictionary Georgian.. Tbilisi. t. 2, p. 31.

9. N. Chopikashvili (1964)Georgian Costume.. Tbilisi. p. 142.

10. Ivane Javakhishvili (1979) History of Georgian Nation. Tbilisi State University, Tbilisi, t. 5. p. 204. 